\title{
Cognitive impairment after acute encephalitis: comparison of herpes simplex and other aetiologies
}

Laura Hokkanen, Erja Poutiainen, Leena Valanne, Oili Salonen, $M$ Iivanainen, Jyrki Launes

\begin{abstract}
Objective-To compare the cognitive defects after acute acyclovir treated herpes simplex encephalitis with those after other types of acute encephalitis.

Methods-Seventy seven consecutive patients between 1985 and 1995 and 29 normal controls were studied. Of the 77 patients without concomitant neurological conditions, 17 had herpes simplex, one virus encephalitis (HSVE group), 27 had some other identified aetiology (nonHSVE group), and in 33 patients the cause was unknown. Acyclovir treatment was started less than four days after the first mental symptoms in 12 of 17 patients with HSVE. A thorough neuropsychological assessment was carried out about one month after the onset.
\end{abstract}

Results-The HSVE group had deficits in verbal memory, verbal-semantic functions, and visuoperceptual functions more often than the non-HSVE group. The risk for cognitive defects was twofold to fourfold in the patients with HSVE compared with the non-HSVE patients. Two (12\%) of the patients with HSVE and $12(44 \%)$ of the non-HSVE patients were cognitively intact. Six patients with HSVE (46\%) and $17(89 \%)$ non-HSVE patients later returned to work. The lesions on CT or MRI were bilateral only in one patient with HSVE. The defects in the three patients with adenovirus infection were severe and resembled the amnesia after HSVE. Cognitive impairment, not previously reported, was found in encephalitis after rotavirus infection and epidemic nephropathy.

Conclusion-The recovery in the HSVE group was better than expected based on the medical literature. On the other hand there were surprisingly severe cognitive defects in encephalitis after other viruses. With early acyclovir treatment patients with the least severe HSVE were equivalent to those with non-HSV encephalitis with good outcome whereas those with the most severe non-HSV encephalitis were equivalent to those with HSVE with poor outcome.

\section{(F Neurol Neurosurg Psychiatry 1996;61:478-484)}

Keywords: encephalitis; cognitive performance; herpes simplex

Acute encephalitis is an inflammation of the brain parenchyma, in most patients caused by viral agents, although bacterial, other microbial, and postinfectious forms are known. In the United States 20000 cases occur each year. ${ }^{1}$ In Finland the prevalence of meningoencephalitis and encephalitis is estimated to be 3.5 cases per $100000 .^{2}$ The aetiology may be difficult to determine and one third to two thirds of the patients lack specific microbial confirmation. ${ }^{34}$ Worldwide, the arboviruses are the most frequent cause of epidemics of encephalitis. In western Europe sporadic infections account for most cases, and the most common single aetiology is herpes simplex 1 virus. ${ }^{5}$ In Sweden the incidence of herpes simplex encephalitis (HSVE) is at least $2 \cdot 3$ cases per million inhabitants per year. ${ }^{6}$

Mental changes as an initial consequence of encephalitis have been reported in all epidemiological studies. ${ }^{478}$ The cognitive defects that persist after the acute stage have seldom been reported in detail. In studies from the United States, the United Kingdom, and Germany the frequency of residual neurological disability has been $10 \%-30 \%$, including aphasia, mental deterioration, and paralysis. ${ }^{3479}$ Neuropsychological investigation was not used in any of these studies.

It has been reported that HSVE results in bilateral temporal lobe damage ${ }^{1011}$ and persistent memory defect. ${ }^{12} 13$ The outcome has been considered poor; death or severe disablement and dependency being the common end points. ${ }^{14}{ }^{15}$ Most of the reported cases originate from the 1970s and early 1980s and since then acyclovir treatment has changed the prognosis of this disease. ${ }^{6}$ Early treatment may have an effect on the long term neuropsychological symptomatology as well, but only small series have so far been published. ${ }^{16} 18$

Even fewer reports have described the neuropsychological findings in acute encephalitis of other aetiologies. In the United States, HSVE accounts for $5 \%-10 \%$ of the annual cases of encephalitis. ${ }^{1}$ In the German series of 53 patients with acute encephalitis, the most common aetiology, HSVE, was identified in nine patients, but $83 \%$ were either caused by other specified agents or were unidentified. ${ }^{4}$

We studied the cognitive sequelae in 77 patients with acute encephalitis between 1985 and 1995.

\section{Material and methods}

PATIENT GROUPS AND CONTROLS

Between 1 January 1985 and 31 December 1994,92 consecutive adult patients under the 
Table 1 Diagnostic methods for determining the specific aetiologies of 44 patients with encephalitis

\begin{tabular}{|c|c|c|c|c|}
\hline Aetiology & $n$ & $C S F$ & Serum & Other \\
\hline Herpes simplex 1 & $\begin{array}{l}12 \\
4 \\
1\end{array}$ & $\begin{array}{l}\text { CF or EIA, } \\
\text { positive PCR in one } \\
\text { CF } \\
\text { High ab titre }\end{array}$ & $\begin{array}{l}\mathrm{CF} \text { or ELA } \\
\text { and pathological s/CSF } \\
\mathrm{CF} \\
\text { and pathological s/CSF }\end{array}$ & \\
\hline Varicella zoster & $\begin{array}{l}4 \\
3 \\
2\end{array}$ & CF or EIA & $\begin{array}{l}\text { High ab titre } \\
\text { CF or EIA } \\
\text { High ab titre }\end{array}$ & $\begin{array}{l}3 \text { with rash } \\
1 \text { with rash } \\
2 \text { with rash and } \\
\text { positive culture }\end{array}$ \\
\hline Influenza B & $\begin{array}{l}2 \\
2\end{array}$ & High ab titre & $\begin{array}{l}\text { High ab titre } \\
\text { and pathological s/CSF } \\
\text { CF, EIA }\end{array}$ & \\
\hline$M$ pneumoniae & 2 & $\begin{array}{l}\text { Mycoplasma RNA } \\
\text { in CSF }\end{array}$ & $\begin{array}{l}\text { High ab titre } \\
\text { and pathological s/CSF }\end{array}$ & \\
\hline Rubella & 2 & $\begin{array}{l}\text { High ab titre, } \\
\text { IgM positive }\end{array}$ & & \\
\hline Tick borne encephalitis & 2 & $\begin{array}{l}\text { High ab titre, } \\
\text { IgM positive }\end{array}$ & High ab titre & \\
\hline Adenovirus & 1 & EIA & $\begin{array}{l}\text { High ab titre } \\
\text { and pathological s/CSF } \\
\text { High ab titre } \\
\text { and pathological s/CSF }\end{array}$ & \\
\hline Adenovirus + borreliosis & 1 & High ab titre for both & $\begin{array}{l}\text { High ab titre for both, } \\
\text { decline in ab titres }\end{array}$ & \\
\hline Rotavirus & 2 & High ab titre & $\begin{array}{l}\text { High ab titres, } \\
\text { positive IgM or } \\
\text { electron microscopy }\end{array}$ & \\
\hline Herpes simplex 2 & 1 & High ab titre & & $\begin{array}{l}\text { Genital lesions } \\
\text { and positive culture }\end{array}$ \\
\hline $\begin{array}{l}\text { Cryptococcus maserans } \\
\text { Epidemic nephropathy } \\
\text { (Puumala virus) }\end{array}$ & $\begin{array}{l}1 \\
1\end{array}$ & $\begin{array}{l}\text { Positive antigen test } \\
\text { High ab titres }\end{array}$ & $\begin{array}{l}\text { High ab titre } \\
\text { and pathological s/CSF }\end{array}$ & \\
\hline
\end{tabular}

age of 75 with acute encephalitis were referred for neuropsychological examination at the Department of Neurology, Helsinki University Central Hospital. It is the only hospital with 24 hour neurological emergency services in the province of Uusimaa (population 1 million), and thus the material includes nearly all adult patients with serious CNS infections in this area during this time. The diagnosis of encephalitis was based on the history, clinical physical and mental findings, and EEG suggesting involvement of the brain parenchyma, findings compatible with infection of the CNS, and CT excluding other causes. Fifteen patients with alcohol misuse, or coexisting or previous neurological disease were excluded. Thus 77 patients with acute encephalitis without concomitant conditions were analysed.

The aetiology was established in 44 (57\%). The analyses were carried out at the Department of Virology, University of Helsinki. Table 1 gives the methods for reaching specific diagnoses. The polymerase chain reaction (PCR) method for the detection of herpes simplex virus-DNA was used in nine patients during 1993-4. Seventeen patients had herpes simplex 1 virus encephalitis (HSVE), nine had varicella zoster virus encephalitis (VZVE), and one had herpes simplex 2 virus (HSV-2) encephalitis. Seventeen had some other identified non-herpetic aetiology as the underlying cause for the encephalitis. The patients were grouped as the HSVE group $(n=17)$, the non-HSVE group $(n=27)$, and the unspecified group ( $n=33$ ).

Follow up EEG and standard laboratory tests were performed on all patients. Neuroradiological follow up was performed using CT in 18 patients and MRI in 31 patients. For analysis, the CT and MRI were scored blindly by two neuroradiologists (OS and LV). In the first CT, which was per- formed within the first three days in most patients, cortical or central atrophy was found in 16 of 77 patients $(20 \%)$. At follow up, CT or MRI disclosed newly developed focal atrophy or focal lesions in $28(36 \%)$ patients.

All patients received specific antibiotic treatment. Along with other medication, 73, including all patients with HSVE, were given intravenous acyclovir ( $30 \mathrm{mg} / \mathrm{kg}$ per day) for a mean of 11.2 (SD $4 \cdot 1$ ) days. One patient with influenza $B$, one with tick borne encephalitis virus, one with epidemic nephropathy, and one with suspicion of tuberculous meningoencephalitis were treated accordingly, without acyclovir medication. In the HSVE group acyclovir treatment was started on the same day as the mental symptoms appeared in two patients, on the next day in five patients, on day 2 in three patients, on day 3 in one patient, on day 4 in one patient, and five or more days after the onset in five patients.

The duration of stay in hospital was 36.4 (SD 38.2), range 8-213 days. After that the patients visited the hospital if necessary. The follow up extended up to the time of subsequent return to work or a decision to retire, maximally one year.

The performance of the patients in the neuropsychological investigation was compared with that of a group of 29 normal controls. Twenty five of the controls had initially volunteered for a study of quantitative EEG (QEEG) and were later willing to participate further. One control was excluded due to a history of probable meningitis. The others had no medical problems and their Q-EEG was normal. Five of the controls were additional volunteers who had no medical complaints and whose neurological examination was normal.

Table 2 shows distributions of age, sex, and education for the HSVE, non-HSVE, and the control groups. There was no difference in age 
Table 2 Sex, age, and education of the patients and the controls, and location of focal findings in follow up CT or MRI in HSVE, non-HSVE, and control groups

\begin{tabular}{|c|c|c|c|}
\hline & $\begin{array}{l}H S V E \\
(n=17)\end{array}$ & $\begin{array}{l}\text { non-HSVE } \\
(n=27)\end{array}$ & $\begin{array}{l}\text { Controls } \\
(n=29)\end{array}$ \\
\hline $\begin{array}{l}\text { Sex }(M / F) \\
\text { Age (y): } \\
\text { Range } \\
\text { Education (y) }\end{array}$ & $\begin{array}{l}8 / 9 \\
50 \cdot 2(12 \cdot 7) \\
23-68 \\
10 \cdot 9(4 \cdot 3)\end{array}$ & $\begin{array}{l}16 / 11 \\
38 \cdot 7(20 \cdot 0) \\
17-73 \\
11 \cdot 2(3 \cdot 7)\end{array}$ & $\begin{array}{l}11 / 18 \\
44 \cdot 4(14 \cdot 1) \\
22-73 \\
12 \cdot 9(3 \cdot 1)\end{array}$ \\
\hline $\begin{array}{l}\text { Focal lesions: } \\
\text { None } \\
\text { Temporal left } \\
\text { Temporal right } \\
\text { Temporal bilateral } \\
\text { Other }\end{array}$ & $\begin{array}{l}3 \\
7 \\
6 \\
1 \\
-\end{array}$ & $\begin{array}{l}\frac{23}{1^{\star}} \\
1 \dagger \\
1 \text { left internal capsule } \neq \\
1 \text { left thalamus } \int\end{array}$ & $\begin{array}{l}\overline{-} \\
\overline{-}\end{array}$ \\
\hline
\end{tabular}

Values for age and education are means (SD)

$\star$ Patient with varicellar zoster viral encephalitis.

†Patient with adenoviral infection and borreliosis (patient 13)

$\ddagger$ Patient with varicellar zoster viral encephalitis.

§Patient with Mycoplasma pneumoniae infection (patient 5).

or duration of education between the three groups (analysis of variance, ANOVA). There was a difference in the Beck depression inventory (BDI) score at the time of the neuropsychological investigation (mean $7 \cdot 2(7 \cdot 8)$ in the HSVE group, $6.9(7 \cdot 8)$ in the non-HSVE group, $2 \cdot 1(2 \cdot 4)$ in the control group, $F=$ $5 \cdot 18, P<0.01)$. Pairwise post hoc analyses disclosed a higher depression score in patients than in controls $(P<0.02$, Tukey's honest significant difference), but no difference between the HSVE and the non-HSVE groups. There was no difference between the HSVE and non-HSVE groups in the frequency of brain atrophy or focal lesions found in the first CT (Pearson's $\chi^{2}$ test). Fourteen patients with HSVE (82\%) had focal lesions in the follow up neuroradiology, whereas the corresponding frequency for the non-HSVE group was $15 \%$ (Pearson's $\chi^{2}=19.7, P<0.0001$ ). Table 2 gives the radiological findings.

To rule out the possibility of error due to selection, we also compared the patients with aetiologically specified encephalitis (both HSVE and non-HSVE, $n=44$ ) with the patients with non-specified encephalitis ( $\mathbf{n}=$ 33). Age, duration of education, and depression scores were similar in the two groups (Student's $t$ test).

\section{NEUROPSYCHOLOGICAL ASSESSMENT}

The neuropsychological examination was carried out in a postacute stage, as soon as the initial confusion had subsided and the patient could cooperate adequately. This was a mean $27 \cdot 5(22 \cdot 8)$, range 5-128 days, after the onset of symptoms. The controls underwent a similar neuropsychological examination.

Table 3 Comparison of mean psychometric test results of the HSVE group, the nonHSVE group, and the controls

\begin{tabular}{|c|c|c|c|c|}
\hline & $\begin{array}{l}\text { HSVE } \\
(n=17)\end{array}$ & $\begin{array}{l}\text { non-HSVE } \\
(n=27)\end{array}$ & $\begin{array}{l}\text { Controls } \\
(n=29)\end{array}$ & $\begin{array}{l}\text { Significant differences } \\
(P<0.05)\end{array}$ \\
\hline $\begin{array}{l}\text { VIQ } \\
\text { Range } \\
\text { PIQ } \\
\text { Range } \\
\text { Verbal memory } \\
\text { Range }\end{array}$ & $\begin{array}{l}97 \cdot 5(25 \cdot 7) \\
37-138 \\
95 \cdot 5(21 \cdot 3) \\
74-143 \\
14 \cdot 4(9 \cdot 3) \\
2 \cdot 5-29 \cdot 5\end{array}$ & $\begin{array}{l}109 \cdot 6(16 \cdot 8) \\
72-130 \\
108 \cdot 1(15 \cdot 2) \\
81-146 \\
27 \cdot 0(6 \cdot 0) \\
14-36\end{array}$ & $\begin{array}{l}121 \cdot 8(12 \cdot 5) \\
104-152 \\
126 \cdot 2(13 \cdot 2) \\
104-159 \\
31 \cdot 8(4 \cdot 5) \\
22 \cdot 5-38\end{array}$ & \multirow{2}{*}{$\begin{array}{l}\text { HSVE } v \text { controls } \\
\text { Non-HSVE } v \text { controls } \\
\text { HSVE } v \text { controls } \\
\text { Non-HSVE } v \text { controls } \\
\text { HSVE } v \text { controls } \\
\text { Non-HSVE } v \text { controls } \\
\text { HSVE } v \text { non-HSVE } \\
\text { HSVE } v \text { controls } \\
\text { Non-HSVE } v \text { controls } \\
\text { HSVE } v \text { non-HSVE }\end{array}$} \\
\hline $\begin{array}{l}\text { Visual memory } \\
\text { Range }\end{array}$ & $\begin{array}{l}23 \cdot 6(8 \cdot 9) \\
12-38\end{array}$ & $\begin{array}{l}31 \cdot 3(4 \cdot 9) \\
21-39\end{array}$ & $\begin{array}{l}35 \cdot 4(3 \cdot 5) \\
27-40\end{array}$ & \\
\hline
\end{tabular}

Values in parentheses are SD.

Significance measured by post hoc Tukey pairwise analysis
The cognitive functions were evaluated in seven different areas. Verbal logical thinking was assessed using the Wechsler adult intelligence scale (WAIS) verbal intelligence quotient (VIQ) ${ }^{19}$ estimated by subtests information, arithmetic, and vocabulary or similarities. Visual logical thinking was assessed with the WAIS performance intelligence quotient (PIQ) estimated by subtests digit symbols, picture completion, and block design. Deficit was considered to exist if the VIQ or the PIQ fell below 95, the lower limit of the normal range in Finnish norms. ${ }^{20}$ Verbal memory was assessed with the Wechsler memory scale (WMS) ${ }^{21}$ subtests logical memory and associative learning, in which the raw scores were added together. Visual memory was assessed by adding together the raw scores of the WMS visual reproduction and the Benton visual retention test. $^{22}$ Verbal-semantic functions were assessed with analysis of the overt speech and understanding of the instructions, confrontation naming of body parts and pictures of familiar objects, and comprehension of sentences with complex semantic structures. ${ }^{23} 24$ Visuoperceptual functions were assessed with tasks of copying a cube and a Greek cross, and of drawing clock hands. Voluntary motor functions were assessed with Luria based tasks of copying spatial movements and sequential movements with arms, hands, and fingers. ${ }^{24}$ Deficits in verbal memory, visual memory, verbal-semantic, visuoperceptual, and voluntary motor functions was considered to exist if the performance in any of the relevant tests fell below the arbitrary cut off point, which was defined as the score two SD below the mean of the controls. The level of depression was assessed with the short form of the Beck depression inventory. ${ }^{25}$ Persistent psychiatric symptoms and personality change were assessed in interviews during the follow up visits.

The occurrence of neuropsychological findings in the HSVE group ( $\mathrm{n}=17$ ) was compared with that in the non-HSVE group ( $n=$ 27 ), and risk ratios as well as $95 \%$ confidence intervals were calculated. The findings in patients with non-herpetic encephalitis are also given in detail. Cases of unspecified aetiology were omitted from these analyses.

\section{Results}

Significant psychometric differences were found between the HSVE, the non-HSVE, and the control groups (ANOVA: VIQ $F(2$, $69)=10.2, \mathrm{P}<0.001$; PIQ $F(2,69)=20.9$, $P<0.001$; verbal memory $F(2,66)=38.8$, $\mathrm{P}<0.001$; and visual memory $F(2,63)=$ $21.4, \quad \mathrm{P}<0.001)$. In pairwise comparison (Tukey's honest significant difference, Spjotvoll/Stoline test), both the HSVE and the non-HSVE group performed worse than the controls in all tests $(P<0.05)$. In the verbal and the visual memory the HSVE group was more impaired than the non-HSVE group $(P<0.001)$. Table 3 gives the neuropsychological findings. 
Table 4 Occurrence of different cognitive deficits of the HSVE and non-HSVE groups and the increased risk for cognitive defects in the HSVE group

\begin{tabular}{lcclc}
\hline Areas of cognitive defect & $\begin{array}{l}\text { HSVE }(n=17) \\
\text { No }(\%)\end{array}$ & $\begin{array}{l}\text { Non-HSVE }(n=27) \\
\text { No }(\%)\end{array}$ & $\begin{array}{l}\text { Risk ratio } \\
(95 \% \text { CI })\end{array}$ & $\chi^{2}(P$ value $)$ \\
\hline Verbal logical thinking & $7(41)$ & $6(22)$ & $1 \cdot 67$ & $1 \cdot 00$ \\
Visual logical thinking & $9(53)$ & $6(22)$ & $2 \cdot 17$ & $3 \cdot 12$ \\
Verbal memory & $13(76)$ & $8(30)$ & $3 \cdot 56(1 \cdot 4-8 \cdot 9)$ & $7 \cdot 39(P<0 \cdot 01)$ \\
Visual memory & $10(59)$ & $9(33)$ & $1 \cdot 88$ & $0 \cdot 81$ \\
Verbal-semantic & $10(59)$ & $11(22)$ & $2 \cdot 50(1 \cdot 1-5 \cdot 8)$ & $4 \cdot 56(P<0 \cdot 05)$ \\
Visuoperceptual & $14(82)$ & $3(11)$ & $1 \cdot 55(1 \cdot 3-5 \cdot 8)$ & $5 \cdot 76(P<0 \cdot 05)$ \\
Voluntary motor & $3(18)$ & $15(56)$ & $3 \cdot 50$ & $0 \cdot 03$ \\
Any cognitive defects & $15(88)$ & $3 \cdot 74$ & 30 \\
\hline
\end{tabular}

Table 4 gives the frequencies of cognitive deficits in HSVE and non-HSVE groups. The HSVE group had a higher frequency of deficits in all measures, and significant differences were found in verbal memory, verbal-semantic functions, and visuoperceptual functions. The risk of defects in the HSVE group was twofold to fourfold compared with the non-HSVE group (table 5). Two of the 17 patients with HSVE (12\%), and 12 of 27 of the non-HSVE patients $(44 \%)$ were cognitively intact. Eleven patients with HSVE $(65 \%)$ had persisting mood or personality change as opposed to three $(11 \%)$ non-HSVE patients (Pearson's $\chi^{2}$ $=13.8, \quad \mathrm{P}<0.001)$. These disturbances included euphoria and manic behaviour, aggressiveness and irritability, and depressive mood. No Klüver-Bucy type of behaviour was seen.

Table 5 presents the neuropsychological findings of patients with non-herpetic aetiology. Neuropsychological test performance of three of the four patients with encephalitis after an influenza B infection (patients 1-3), and both patients with Mycoplasma pneumoniae (patients 5-6), rubella (patients 7-8), and arbovirus (patients 9-10) encephalitis were rated intact. One patient with influenza B infection had slightly lowered VIQ and mild inaccuracy in visuoperceptual performance. The two patients with adenovirus infection and the one with simultaneous borrelia and adenovirus infection (patients 11-13) all had a clear memory defect, as well as circumscribed neuropsychological findings, including verbalsemantic or visuoperceptual difficulty. One patient with rotavirus infection (patient 14) was inaccurate in visuoperceptual functions, the other (patient 15) had memory defects. Cryptococcal infection (patient 16) led to persistent epilepsy, slowness, general deterioration, and retirement. Epidemic nephropathy (patient 17) resulted in visuoperceptual difficulty and hand dyspraxia. Findings for patients with VZVE will be reported in detail separately, and are not discussed here. The patient with HSV-2 had marginal difficulty in attention and mild inaccuracy in visuoperceptual functions.

Two patients died of cancer but no deaths related to encephalitis occurred in this study population during the follow up period. Twenty nine patients with a non-specified aetiology (total $n=33$ ) were employed before the onset of illness. Of these, $23(79 \%)$ were able to return to their initial occupation. Thirty two patients with a specified aetiology (total $n=44$ ) were employed before the onset of illness, and of those, $23(72 \%)$ were able to return to work. The percentage of patients who were able to return to work was similar in the specified and non-specified group (Pearson's $\chi^{2}$ test). Six of the HSVE group ( $46 \%$ of the 13 who were employed) and 17 of the non-HSVE patients $(89 \%$ of the 19 who were employed) returned to work after illness, which means a poorer outcome for the HSVE patients (Pearson's $\chi^{2}=7.2, P<0.01$ ). In patients with HSVE, the duration of sick leave was $133.5(80 \cdot 1)$, range $63-251$ days, and in non-HSVE patients $84 \cdot 2(67 \cdot 3)$, range $13-271$ days, after the onset of symptoms (no difference by Student's $t$ test).

No differences in any of the cognitive measures were found between patients with a specified aetiology (both HSVE and non-

Table 5 Neuropsychological findings in patients with non-herpetic encephalitis

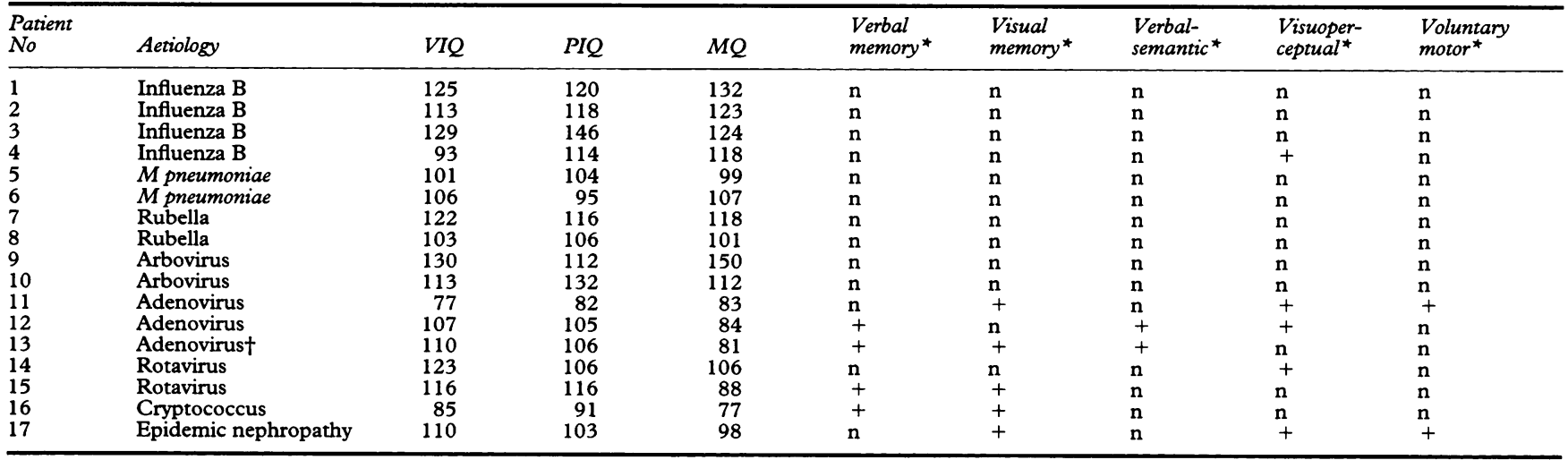

*The defined cut off point was 2 SD below the mean of the controls. $\mathrm{n}=$ Normal range; $\dagger$ Infection in conjunction with borreliosis; $+=$ Abnormal finding in any of the test measuring the function. 
Table 6 Literature concerning adult cases of non-herpetic encephalitis

\begin{tabular}{|c|c|c|}
\hline Aetiology (reference) & Observations on cognition & Usual outcome \\
\hline Influenza $^{5760}$ & $\begin{array}{l}\text { Impaired memory, } \\
\text { persisting confusion }\end{array}$ & $\begin{array}{l}\text { Varies from fatal to complete } \\
\text { recovery }\end{array}$ \\
\hline M pneumoniae $e^{61.65}$ & $\begin{array}{l}\text { Confusion, psychotic } \\
\text { episodes }\end{array}$ & $\begin{array}{l}\text { Varies from fatal to complete } \\
\text { recovery }\end{array}$ \\
\hline Rubella $^{6667}$ & $\begin{array}{l}\text { Confusion, aphasia, } \\
\text { emotional liability }\end{array}$ & $\begin{array}{l}\text { Varies from fatal to complete } \\
\text { recovery }\end{array}$ \\
\hline $\begin{array}{l}\text { Tick borne encephalitis }{ }^{68-71} \\
\text { (Kumlinge virus) }\end{array}$ & $\begin{array}{l}\text { Confusion, speech defects, } \\
\text { persistent fatigability, } \\
\text { one case of dementia }\end{array}$ & Complete recovery \\
\hline Adenovirus $^{51-53}$ & $\begin{array}{l}\text { Confusion, agitation, } \\
\text { period of amnesia }\end{array}$ & Good recovery \\
\hline $\begin{array}{l}\text { Rotavirus } \\
\text { Cryptocuccosus } \\
\text { 72-75 }\end{array}$ & $\begin{array}{l}\text { No reports on adults } \\
\text { Confusion, personality } \\
\text { change, psychotic episodes, } \\
\text { memory defect, dementia }\end{array}$ & $\begin{array}{l}\text { Varies from fatal to complete } \\
\text { recovery }\end{array}$ \\
\hline Epidemic nephropathy ${ }^{76} 77$ & No details & Good recovery \\
\hline
\end{tabular}

HSVE, $n=44)$ and the patients with unspecified encephalitis $(n=33)$ analysed either by group means or frequencies of deficits.

\section{Discussion}

The cognitive deficits in patients with HSVE were more frequent as well as more severe than in those with non-HSVE. Intellectual functions and logical thinking were not statistically more impaired in patients with HSVE, but the HSVE group had more deficits in memory functions and in verbal-semantic and visuoperceptual functions. In the postacute stage, the risk for cognitive defects in HSVE was twofold to fourfold compared with a nonHSVE group. However, the variability was high, as the $95 \%$ confidence intervals of the risk ratios ranged from 1 to 9 . Some patients with HSVE were cognitively intact. In a recent study, ${ }^{13}$ dense amnesia was found in six of 10 patients with HSVE and a noticeable anterograde memory impairment in the four others. However, in that study memory impairment was an inclusion criteria, which explains the abundant findings. Only a few studies have described mild forms of HSVE. ${ }^{17} 26$

The neuropsychological assessment was carried out about one month after the onset of symptoms. The cognitive status cannot be regarded as final at that stage, and therefore we contined to follow up the patients to see whether the patients later became employed or retired. Almost half of the patients with HSVE, along with $89 \%$ of the non-HSVE patients, were eventually able to return to work. Although neuropsychological findings and psychiatric symptoms may be moderate to severe during the first weeks and months after the onset, improvement takes place within the first year and the outcome of HSVE may be more favourable than has been reported previously.

The good outcome in HSVE is also reflected in the fact that the radiological findings in our patients were mostly unilateral. This is by contrast with previous neuropathological ${ }^{10}$ as well as $M \mathrm{MI}^{13}$ findings, which suggested that the damage in HSVE is nearly always bilateral. Progression of the lesion from unilateral to bilateral used to be common, ${ }^{27}$ but after the introduction of acyclovir treatment such advanced cases have become rarer. Unilateral findings, resulting in only mild neu- ropsychological sequelae, have been reported in other studies. ${ }^{182829}$ The neuropsychological profile in some of our patients suggested bilateral damage, which was not detected in neuroradiological imaging. Repeated MRI was not obtained in all patients, and minor lesions may have gone unseen. However, pronounced asymmetry was evident.

We think that the good outcome in our series is due to the fact that acyclovir medication was initiated very early, during the first four days of the onset in 12 of 17 patients. We did not wait for the HSVE diagnosis to be confirmed, but started medication at the mere suspicion of HSVE. Treatment latencies of less than four days have been reported to correlate with a favourable outcome. ${ }^{3031}$

We used clinically available standard CSF and serum laboratory tests for establishing the aetiological diagnosis. The retrospective diagnosis of HSVE was based on the rise in the antibody titres in the CSF and a pathological serum:CSF antibody ratio. Simultaneous rise in serum antibody titres was considered confirmatory. The same methods performed by the same laboratory have been used in previous epidemiological studies. ${ }^{32} 33$ These methods have also been widely used by others. ${ }^{34-38}$ The problems in laboratory verification of HSVE have been known for decades ${ }^{39}$ and biopsy has been suggested as the only reliable method. ${ }^{140}$ As acyclovir treatment is safe and controversy over the risks and benefits of biopsy exist, ${ }^{41}{ }^{42}$ biopsy samples were not taken in our patients. Recently, the PCR technique has been proved reliable in the diagnosis ${ }^{43-47}$ and this method was used as soon as it became available to us.

This study did not include all patients treated for acute encephalitis in the Department of Neurology. It consisted of those referred for neuropsychological examination. Patients who died in the early phase were not included. On the other hand, a few patients without specific aetiological diagnosis who were discharged rapidly due to mild course of disease were also left out. Therefore, the possible bias in the inclusion of cases is bidirectional and probably does not distort the results. Also the fact that only specified aetiologies were included in the analyses might produce error. However, the patients with a specified encephalitis had neither more nor less cognitive defects than the patients with non-specified encephalitis, and the percentage of patients later returning to work was similar in these groups.

Table 6 gives the relevant medical literature concerning non-herpetic aetiologies. Reports on the cognitive status are scant and often limited to the acute stage. Neuropsychological assessment has usually not been made. Outcome also varies, and whereas reports from earlier decades often present fatal cases, more recent reports include total recoveries. In our series almost all patients with influenza $B$, Mycoplasma pneumoniae, rubella, and TBE virus encephalitis had no cognitive sequelae. One patient with influenza $B$ virus and both patients with rotavirus encephalitis had resid- 
ual neuropsychological problems at the postacute assessment, but they recovered and returned to work. The patient with cryptococcosis was forced to retire because of cognitive decline and epilepsy. Cognitive defects were also found in one patient with encephalitis after epidemic nephropathy, the Scandinavian form of haemorrhagic fever with renal syndrome.

Infection of the CNS caused by members of the adenovirus group have been reported mostly in children. ${ }^{48-50}$ Reports of adenovirus encephalitis in adult patients are scarce and all patients have had concomitant diseases. ${ }^{51-53}$ In one of them nuclear inclusions and focal necrosis of grey matter was found at necropsy. We studied two patients with adenoviral encephalitis without concomitant diseases, and one patient with concurrent borreliosis. They all had a neuropsychological profile suggesting severe CNS dysfunction. Borrelia burgdorferi infection may in itself result in various CNS manifestations and cognitive deficits. ${ }^{54-56}$ Although the bilateral hippocampal damage seen in MRI and the findings in neuropsychological assessment were not typical of Lyme disease, we cannot exclude the impact of borreliosis in this case. Memory defect was clear in all three patients with adenovirus infection and two of them had an amnesic type impairment, in which delayed memory was impaired. They also had mood changes and irritability. They later returned to work (two studying, one to short term jobs) but have all had difficulties.

In conclusion, the risk for cognitive deficits was twofold to fourfold in patients with HSVE compared with non-HSVE patients but almost half of the HSVE patients were later able to return to work. The sequelae of adenovirus encephalitis were surprisingly severe and specific, resembling the amnesia after HSVE. With rapid acyclovir treatment, the least severe cases of HSVE were equivalent to the non-HSV encephalitis cases with good outcome, whereas the most severe cases of nonHSV encephalitis were equivalent to the cases with HSVE with poor outcome,

We thank Dr Esko Matikainen at the Institute of Occupationa Health for the invaluable help in providing the control group.

1 Hanley DF, Johnson RT, Whitley RJ. Yes, brain biopsy should be a prerequisite for herpes simplex encephalitis treatment. Arch Neurol 1987;44:1289-90.

2 Palo J, Jokelainen $M$, Kaste M, Teräväinen $\mathrm{H}$, Waltimo $\mathrm{O}$. Neurological diseases: infections. In: Neurology. Porvoo: WSOY, 1984:371-92.

3 Meyer HM, Johnson RT, Crawford IP, Dascomb HE, Rogers NG. Central nervous system syndromes of "viral" etiology. A study of 713 cases. Am F Med 1960;29. $334-47$.

4 Buttner T, Dorndorf W. Viral encephalitis. Experiences with 53 patients in Middle Hessia. Fortschr Neurol Psychiatr 1988;56:315-25.

5 Wood M, Anderson M. Acute encephalitis. In: Neurological infections. London: WB Saunders, 1988:381-486.

6 Sköldenberg B, Forsgren M, Alestig K, et al. Acyclovir versus vidarabine in herpes simplex encephalitis. Randomised multicentre study in consecutive Swedish patients. Lancet 1984;ii:707-11.

7 Miller JD, Ross CA. Encephalitis. A four-year survey. Lancet 1968;i:1121-6.

8 Beghi E, Nicolosi A, Kurland LT, Mulder DW, Hauser WA, Shuster L. Encephalitis and aseptic meningitis, Olmsted County, Minnesota, 1950-1981: I. Epidemiology. Ann Neurol 1984;16:283-94. 9 Kennard C, Swash M. Acute viral encephalitis: its diagnosis
and outcome. Brain 1981;104:129-48.

10 Hierons R, Janota I, Corsellis JA. The late effects of necro- tizing encephalitis of the temporal lobes and limbic areas: a clinico-pathological study of 10 cases. Psychol Med 1978;8:21-42.

11 Yoneda Y, Mori E, Yamashita H, Yamadori A. MRI volumetry of medial temporal lobe structures in amnesia following herpes simplex encephalitis. Eur Neurol 1994; 34:243-52.

12 Rose FC, Symonds CP. Persistent memory defect following encephalitis. Brain 1960;83:195-212.

13 Kapur N, Barker S, Burrows EH, et al. Herpes simplex encephalitis: long term magnetic resonance imaging and neuropsychological profile. $\mathcal{F}$ Neurol Neurosurg Psychiatry neuropsychological

14 Oxbury JM, MacCallum FO. Herpes simplex virus encephalitis: clinical features and residual damage. encephalitis: clinical features
Postgrad Med $f_{1973 ; 49: 387-9 .}$

15 Kennedy PG. A retrospective analysis of forty-six cases of herpes simplex encephalitis seen in Glasgow between 1962 and 1985. Qf Med 1988;68:533-40

16 Gordon B, Selnes OA, Hart J, Hanley DF, Whitley RJ. Long-term cognitive sequelae of acyclovir-treated herpes simplex encephalitis. Arch Neurol 1990;47:646-7.

17 Counsell CE, Taylor R, Whittle IR. Focal necrotising herpes simplex encephalitis: a report of two cases with good clinical and neuropsychological outcomes. F Neurol Neurosurg Psychiatry 1994;57:1115-7.

18 Laurent B, Allegri RF, Thomas-Anterion C, Foyatier N, Naegele-Faure B, Pellat J. Long-term neuropsychological follow-up in patients with herpes simplex encephalitis follow-up in patients with herpes simplex encephalitis and predominantly left

19 Wechsler D. Wechsler adult intelligence scale. New York: The Psychological Corporation, 1955.

20 Wechsler D. Wechsler adult intelligence scale. WAIS manual. Helsinki: Psykologien Kustannus OY, 1970.

21 Wechsler D. Standardized memory scale for clinical use. $\mathcal{F}$ Psychol 1954;19:87-95.

22 Benton A. The revised visual retention test. New York: The Psychological Corporation, 1974.

23 Luria AR. The investigation of speech processes. Comprehension of grammatical structure. In: Traumatic aphasia. Its syndromes, psychology and treatment. The Hague: Mouton, 1970:314-322.

24 Christensen AL. Luria's Neuropsychological Investigation. Text. Copenhagen: Munksgaard, 1975.

25 Beck AT, Beck RW. Screening depressed patients in family practise, a rapid technique. Postgrad Med $\mathcal{f} 1972$; practise, a rapid

26 Klapper PE, Cleator GM, Longson $M$. Mild forms of herpes encephalitis. $\mathcal{f}$ Neurol Neurosurg Psychiatry 1984;47: $1247-50$

27 Koskiniemi M, Ketonen L. Herpes simplex virus encephalitis: progression of lesion shown by CT. $\mathcal{F}$ Neurol 1981;225:9-13.

28 Eslinger PJ, Damasio H, Damasio AR, Butters N. Nonverbal amnesia and asymmetric cerebral lesions following encephalitis. Brain Cogn 1993;21:140-52.

29 Laurent B, Allegri RF, Michel D, et al. Primarily unilateral herpes encephalitis. Long-term neuropsychological study of 9 cases. Rev Neurol (Paris) 1990;146:671-81.

30 Whitley RJ, Alford CA, Hirsch MS, et al. Vidarabine versus acyclovir therapy in herpes simplex encephalitis. N Engl f Med 1986;314:144-9.

31 Whitley RJ, Alford CA, Hirsch MS, et al. Factors indicative of outcome in a comparative trial of acyclovir and vidarabine for biopsy-proven herpes simplex encephalitis. Infection 1987;15 (suppl 1):S3-8.

32 Koskiniemi M, Rautonen J, Lehtokoski Lehtiniemi E, Vaheri A. Epidemiology of encephalitis in children: a 20year survey. Ann Neurol 1991;29:492-7.

33 Färkkila M, Koskiniemi M, Vaheri A. Clinical spectrum of neurological herpes simplex infection. Acta Neurol Scand 1993;87:325-8.

34 Klapper PE, Laing I, Longson M. Rapid non-invasive diagnosis of herpes encephalitis. Lancet 1981 ;ii:607-9.

35 Nahmias AJ, Whitley RJ, Visintine AN, Takei Y, Alford CA. Herpes simplex virus encephalitis: laboratory evaluations and their diagnostic significance. $\mathcal{F}$ Infect Dis 1982;145:829-36.

36 Kahlon J, Chatterjee S, Lakeman FD, Lee F, Nahmias AJ, Whitley RJ. Detection of antibodies to herpes simplex Whitley RJ. Detection of antibodies to herpes simplex
virus in the cerebrospinal fluid of patients with herpes virus in the cerebrospinal fluid of patients with

37 Lakeman FD, Koga J, Whitley RJ. Detection of antigen to herpes simplex virus in cerebrospinal fluid from patients with herpes simplex encephalitis. F Infect Dis 1987; 155:1172-8.

38 Aurelius E. Herpes simplex encephalitis. Early diagnosis and immune activation in the acute stage and during long-term follow-up. Scand F Infect Dis Suppl 1993;89: 3-62.

39 Johnson RT, Olson LC, Buescher EL. Herpes simplex virus infections of the nervous system. Problems in laboratory diagnosis. Arch Neurol 1968;18:260-4.

40 Morawetz RB, Whitley RJ, Murphy DM. Experience with brain biopsy for suspected herpes encephalitis: a review
of forty consecutive cases. Neurosurgery 1983;12:654-7.

41 Anderson NE, Willoughby EW, Synek BJ, Croxson MC, Glasgow GL. Brain biopsy in the management of focal Glasgow GL. Brain biopsy in the management of focal
encephalitis. I Neurol Neurosurg Psychiatry 1991;54: 1001-3.

42 Fishman RA. No, brain biopsy need not be done in every patient suspected of having herpes simplex encephalitis. patient suspected of having her 
43 Rowley AH, Whitley RJ, Lakeman FD, Wolinsky SM. Rapid detection of herpes-simplex-virus DNA in cerebrospinal fluid of patients with herpes simplex encephalitis. Lancet 1990;335:440-1.

44 Aurelius E, Johansson B, Sköldenberg B, Staland A, Forsgren M. Rapid diagnosis of herpes simplex encephalitis by nested polymerase chain reaction assay of cerebrospinal fluid. Lancet 1991;337:189-92.

45 Anderson NE, Powell KF, Croxson MC. A polymerase chain reaction assay of cerebrospinal fluid in patients with suspected herpes simplex encephalitis. F Neurol Neurosurg Psychiatry 1993;56:520-5.

46 Tyler KL. Polymerase chain reaction and the diagnosis of viral central nervous system diseases. Ann Neurol 1994; 36:809-11.

47 Lakeman FD, Whitley RJ. Diagnosis of herpes simplex encephalitis: application of polymerase chain reaction to cerebrospinal fluid from brain-biopsied patients and corcerebrospinal fluid from wrain-biopsied patients and correlation with disease. National Institute of Allergy and Infectious Diseases Collaborativ

48 Gabrielson MO, Joseph C, Hsiung GD. Encephalitis associated with adenovirus type 7 occurring in a family outbreak. $\Im$ Pediatr 1966;68:142-4

49 Huttunen L. Adenovirus type 7-associated encephalitis. Scand $\mathcal{F}$ Infect Dis 1970;2:151-3.

50 Kelsey DS. Adenovirus meningoencephalitis. Pediatrics 1978;61:291-3.

51 Chou SM, Roos R, Burrell R, Gutmann L, Harley JB. Subacute focal adenovirus encephalitis. $\mathcal{f}$ Neuropathol Exp Neurol 1973;32:34-50.

52 Kelsey DS, McLean WT. Adenoviral meningoencephalitis in a patient with lead toxicity. Arch Neurol 1979;36: in a patic

53 West TE, Papasian CJ, Park BH, Parker SW. Adenovirus type 2 encephalitis and concurrent Epstein-Barr virus infection in an adult man. Arch Neurol 1985;42:815-7.

54 Pachner AR, Duray P, Steere AC. Central nervous system manifestations of Lyme disease. Arch Neurol 1989;46: $790-5$.

55 Krupp LB, Masur D, Schwartz J, et al. Cognitive functioning in late Lyme borreliosis. Arch Neurol 1991;48: 1125-9.

56 Halperin JJ, Luft BJ, Anand AK, et al. Lyme neuroborreliosis: central nervous system manifestations. Neurology 1989;39:753-9.

57 Flewett TH, Hoult JG. Influenzal encephalopathy and postinfluenzal encephalitis. Lancet 1958;ii:11-15.

58 McConkey B, Oxon BM, Daws RA. Neurological disorders associated with Asian influenza. Lancet 1958;15-17.

59 Sulkava $R$, Rissanen A, Pyhälä R. Post-influenzal encephalitis during the influenza A outbreak in encephalitis during the influenza A outbreak in

60 Hawkins SA, Lyttle JA, Connolly JH. Two cases of influenza B encephalitis [letter]. $\mathcal{f}$ Neurol Neurosurg
Psychiatry 1987;50:1236-7.

61 Pönkä A. The occurrence and clinical picture of serologically verified Mycoplasma pneumoniae infections with emphasis on central nervous system, cardiac and join manifestations. Annals of Clinical Research 1979;11(supp 24):1-60.

62 Decaux G, Szyper M, Ectors M, Cornil A, Franken L. Central nervous system complications of Mycoplasm pneumoniae. I Neurol Neurosurg Psychiatry 1980;43 883-7.

63 Fisher RS, Clark AW, Wolinsky JS, Parhad IM, Moses H, Mardiney MR. Postinfectious leukoencephalitis complicating Mycoplasma pneumoniae infection. Arch Neurol 1983;40:109-13

64 Abramovitz P, Schvartzman P, Harel D, Lis I, Naot Y. Direct invasion of the central nervous system by Mycoplasma pneumoniae: a report of two cases. $\mathcal{f}$ Infect Dis 1987;155:482-7.

65 Weinblatt ME, Caplan ES. Fatal Mycoplasma pneumoniae encephalitis in an adult. Arch Neurol 1980;37:321

66 Miller HG, Stanton JB, Gibbons JL. Para-infectious encephalomyelitis and related syndromes: a critical review of the neurological complications of certain spereview of the neurological complication
cific fevers. $Q \mathcal{F}$ Med 1956;25:427-505.

67 Ikemura Y, Akena H, Okada A. Postinfectious rubella encephalitis. Nervenarzt 1984;55:83-5.

68 Ziebart-Schroth A. Tick-borne meningoencephalitis: clinical picture and unusual features. Wien Klin Wochensch 1972;84:778-81.

69 Ackermann R, Rehse Kupper B. Central European encephalitis in the Federal Republic of Germany. Fortschr Neurol Psychiatr Grenzgeb 1979;47:103-22.

70 Conrads R, Plassmann E. Meningo encephalitis (FSME). Fortschr Med 1982;100:799-801.

71 Wahlberg $P$, Saikku P, Brummer Korvenkontio M. Tickborne viral encephalitis in Finland. The clinical features borne viral encephalitis in Finland. The clinical features of Kumlinge diseas

72 Lewis JL, Rabinovich S. The wide spectrum of cryptococcal infections. Am $\mathcal{F}$ Med 1972;53:315-22.

73 Weenink HR, Bruyn GW. Cryptococcosis of the nervous system. In: Vinken PJ, et al, eds. Handbook of clinical neurology. Amsterdam: Elsevier/North-Holland Biomedical Press, 1978:459-502.

74 Steiner I, Polacheck I, Melamed E. Dementia and myoclonus in a case of cryptococcal encephalitis. Arch Neurol 1984;41:216-7.

75 Yu YL, Lau YN, Woo E, Wong KL, Tse B. Cryptococcal infection of the nervous system. $Q \mathcal{F} M e d$ 1988;66:87-96.

76 Lähdevirta J, Savola J, Brummer-Korvenkontio M, Bernd $R$, Illikainen $R$, Vaheri A. Clinical and serological diagnos, ilikainen $R, V$ aheri A. Clinical and serological diagnosis of nephropatia epidemica, the mild type of haemor-

77 Launes J, Hautanen A. Nephropathia epidemica encephalitis. Acta Neurol Scand 1988;78:234-5. 